University of Nebraska - Lincoln

DigitalCommons@University of Nebraska - Lincoln

Publications from USDA-ARS / UNL Faculty

U.S. Department of Agriculture: Agricultural

Research Service, Lincoln, Nebraska

2005

\title{
Phosphorus Dynamics in Broiler Litter-Amended Soils
}

\author{
A. Adeli \\ USDA-ARS, aadeli@msa-msstate.ars.usda.gov \\ K. R. Sistani \\ USDA-ARS \\ M. F. Bal'a \\ USDA-ARS \\ D. E. Rowe \\ USDA-ARS
}

Follow this and additional works at: https://digitalcommons.unl.edu/usdaarsfacpub

Part of the Agricultural Science Commons

Adeli, A.; Sistani, K. R.; Bal'a, M. F.; and Rowe, D. E., "Phosphorus Dynamics in Broiler Litter-Amended Soils" (2005). Publications from USDA-ARS / UNL Faculty. 510.

https://digitalcommons.unl.edu/usdaarsfacpub/510

This Article is brought to you for free and open access by the U.S. Department of Agriculture: Agricultural Research Service, Lincoln, Nebraska at DigitalCommons@University of Nebraska - Lincoln. It has been accepted for inclusion in Publications from USDA-ARS / UNL Faculty by an authorized administrator of DigitalCommons@University of Nebraska - Lincoln. 


\title{
Phosphorus Dynamics in Broiler Litter-Amended Soils
}

\author{
A. Adeli, K. R. Sistani, M. F. Bal'a and D. E. Rowe \\ USDA-ARS, Waste Management and Forage Research Unit, \\ Mississippi State, Mississippi, USA
}

\begin{abstract}
Because land application of broiler litter is commonly made in the spring before cropping season and in the fall, it is essential to understand how environmental variations, such as temperature, affect the phosphorus $(\mathrm{P})$ dynamics. A laboratory incubation study was conducted at Waste Management and Forage Research Unit, USDAARS with the objective of determining the effects of temperature and soil properties on water-soluble P (WSP), Mehlich $3 \mathrm{P}$, and P fractions in broiler litter-amended soils. Broiler litter was mixed with three soils (Leeper silty clay, Grenada silt loam, and Ruston sandy loam) at the rate of $10 \mathrm{Mg} \mathrm{ha}^{-1}$. The mixtures were incubated at $18^{\circ} \mathrm{C}, 25^{\circ} \mathrm{C}$, and $32^{\circ} \mathrm{C}$ for up to 90 days and repeated three times. Soil samples were taken at eight time intervals $(2,5,10,15,30,60$, and 90 days) and analyzed for water-soluble $\mathrm{P}$ and Mehlich 3-extractable $\mathrm{P}$ (MEP). Phosphorus also was fractionated chemically into inorganic and organic components by sequential extraction for soil samples taken at the end of incubation period (90 days). Water-soluble $\mathrm{P}$ decreased rapidly after a 15-day incubation in all soils for all temperatures and followed to a steady state to the end of incubation period. Averaged across temperatures, broiler litter application resulted in a significant increase in all fractions compared with controls. However, the increase was greater for inorganic than for organic fractions. The concentration of calcium (Ca)-P fraction was highest in calcareous Grenada soil, which suggests that the presence of carbonates influence the fate of $\mathrm{P}$ from applied broiler litter. The coarse textured Ruston contained a greater concentration of water-soluble P (WSP) than the other soils. At $32^{\circ} \mathrm{C}$, the concentration of plantavailable $\mathrm{P}$ fractions [bicarbonate inorganic P (IP) and hydroxide IP] significantly
\end{abstract}

Received 4 December 2003, Accepted 17 June 2004

Contribution of the Mississippi Agricultural and Forestry Experiment Station, journal paper no. J10120.

Address correspondence to A. Adeli, USDA-ARS, Waste Management and Forage Research Unit, Mississippi State, MS 39672, USA. E-mail: aadeli@msa-msstate.ars. usda.gov 
increased and WSP decreased. It is likely that the higher temperature $\left(32^{\circ} \mathrm{C}\right)$ promotes higher biological activity and lower water-soluble $\mathrm{P}$ than lower temperature.

Keywords: Broiler litter, extractable phosphorus, phosphorus fractionation, water-soluble P

\section{INTRODUCTION}

Broiler litter is considered as a good source of phosphorus $(\mathrm{P})$, potentially equivalent to inorganic fertilizer (Malone 1992). This is true in part because most of the $\mathrm{P}$ in poultry litter is inorganic, as high as $88-90 \%$ of the total $\mathrm{P}$ (Sharpley and Moyer 2000). Although $P$ is an essential plant nutrient, it can cause undesirable agronomic and environmental effects when present in soil at excessive levels (Sharpley and Menzel 1987). Efficient agronomic use of broiler litter requires information on its nutrient contribution to the soil-crop system. The availability of broiler litter-derived $\mathrm{P}$ to plant uptake depends on forms as well as magnitude of P (Sharpley and Moyer 2000). Also from an environmental standpoint, the identification of the inorganic and organic $\mathrm{P}$ fractions in litter-amended soil is important in terms of potential nutrient sources for loss in runoff (Vaithiyanathan and Correll 1992). More information about the forms of $\mathrm{P}$ and the specific chemical fractions of $\mathrm{P}$ in broiler litter-amended soils is needed in understanding the chemistry and fate of $\mathrm{P}$ in soils. Because the chemistry of soil $\mathrm{P}$ is so complex, the classes of soil $\mathrm{P}$ forms are often defined by the extractants that remove them from soil material in a sequential fractionation scheme. Sequential fractionation procedures are based on the assumption that chemical extractants dissolve different groups of $\mathrm{P}$ forms. Therefore, fractionation studies are useful to obtain information about the $\mathrm{P}$ forms, which has been useful for interpretations of soil development (Smeck 1985; Cross and Schlesinger 1995; Nair, Graetz, and Portier 1995) as well as potential plant availability of P (Tiessen and Moir 1993; Cox, Camberato, and Smith 1997).

Because various forms of $\mathrm{P}$ have different solubility (Chang and Jackson 1957), distribution of $P$ fractions might indicate availability of $P$ for plant uptake or stimulate eutrophication in surface water bodies. In recent studies, it has been reported that poultry litter applications increased inorganic $\mathrm{P}$ fraction from 15 to $187 \mathrm{mg} \mathrm{kg}^{-1}$ as bicarbonate-extractable P (Sharpley, Troeger, and Smith 1991). It was also reported that the fraction of P in soil and sediment extracted with $0.1 M \mathrm{NaOH}$ was correlated well with algal uptake of P (Sharpley, Troeger, and Smith 1991). Most efficient management of broiler litter, therefore, will depend on a better understanding of the rate and forms at which $\mathrm{P}$ becomes available and in particular, how the rate varies with environmental conditions such as temperature. Temperature would seem to be critical in broiler $\mathrm{P}$ cycling because of the activities of soil microorganisms (Smith, Munson, and Coyea 1998). Smith et al. (1998) reported that increase in temperature resulted in pulse of microbial activity followed by 
increase in dissolved organic $\mathrm{P}$, which is an important part of $\mathrm{P}$ cycling. In another study conducted on a sandy soil from north central of Florida, it was reported that an increase in incubation temperature from $15^{\circ} \mathrm{C}$ to $38^{\circ} \mathrm{C}$ resulted in an increase of between $13 \%$ and $53 \%$ in $\mathrm{KCl}$-extractable inorganic P (Grierson, Comerford, and Jokela 1999). Soil type could be considered as another factor that may affect $\mathrm{P}$ mineralization. In a study conducted by Torbert et al. (1995), however, the potential P mineralization was not affected by soil types, and the average $\mathrm{P}$ concentration in collected leachate was reported to be $0.1,0.06$, and $0.08 \mathrm{mg} \mathrm{P} \mathrm{kg}^{-1}$ soil for clay loam, silt loam, and loamy sand, respectively.

Chemical fractionation procedures have been used to identify the various forms of $\mathrm{P}$ in soil receiving poultry manure (Sharpley and Moyer 2000; Mozaffari and Sims 1996) and dairy manure (Nair, Graetz, and Portier 1995; Gale et al. 2000). In most studies, the effect of temperature on P mineralization and fractionations in soils amended with animal wastes have been conducted typically under a constant single incubation temperature (Mozaffari and Sims 1996; Reddy et al. 1980; Field, Renau, and Kroontij 1985). Because broiler litter is applied in the spring and fall and exposed to different seasonal temperature, it is essential to understand how temperature variations affect $\mathrm{P}$ availability in the soils in terms of potential $\mathrm{P}$ for plant uptake or loss in runoff. The effects of temperature on the potential P mineralization and $\mathrm{P}$ fractions in soils amended with broiler litter is less known.

The objective of this study was to quantitatively determine the effects of temperature on available $\mathrm{P}$ and $\mathrm{P}$ fractions in soils amended with broiler litter.

\section{MATERIALS AND METHODS}

\section{Soil Collection and Characterization}

This study was conducted at a USDA-ARS Waste Management and Forage Research Unit laboratory in Mississippi. Three soils were used in this study including Leeper clay loam (fine, smectitic, nonacid, thermic Vertic Epiaquepts), Grenada silt loam (fine-silty, mixed, active, thermic Oxyaquic Fraglossudalfs), and Ruston sandy loam (fine-loamy, siliceous, semiactive, thermic Typic Paleudults). Soils were chosen on the basis of wide differences in physical and chemical characteristics (Table 1). The Ruston soil is very sandy and well drained with low organic matter. The Grenada soil is moderately drained and usually contains higher contents of clay and organic matter than the Ruston soil. The Leeper soil contains high organic matter and is a poorly drained clay loam soil. The soils used were typical for the region where the broiler litter was produced and it would be land-applied. The soils had not received any kind of organic or inorganic fertilizer for the previous 6 years. Initial chemical analysis of soils indicated that Ruston soil is testing low in P, but Leeper and Grenada soils are testing medium in P levels (Table 1). 
Table 1. Initial physical and chemical characteristics of soils at the $0-$ to $15-\mathrm{cm}$ depth used for incubation

\begin{tabular}{|c|c|c|c|}
\hline \multirow[b]{2}{*}{ Parameter } & \multicolumn{3}{|c|}{ Soil series } \\
\hline & Leeper & Grenada & Ruston \\
\hline Textural class & Clay loam & Silty clay loam & Sandy loam \\
\hline Clay, \% & 62 & 27 & 11 \\
\hline Silt, \% & 32 & 65 & 27 \\
\hline Sand, \% & 6 & 8 & 62 \\
\hline $\mathrm{PH}^{a}$ & 6.5 & 7.1 & 6.0 \\
\hline Organic matter, $\mathrm{g} \mathrm{kg}^{-1}$ & 28.5 & 21.2 & 11.9 \\
\hline $\mathrm{CEC}, \mathrm{cmol}_{\mathrm{c}} \mathrm{kg}^{-1}$ & 30.2 & 22.3 & 8.2 \\
\hline Total $\mathrm{N}, \mathrm{g} \mathrm{kg}^{-1}$ & 0.29 & 0.08 & 0.05 \\
\hline Water-soluble $\mathrm{P}, \mathrm{mg} \mathrm{kg}^{-1}$ & 1.92 & 2.94 & 5.08 \\
\hline Mehlich $3 \mathrm{P}, \mathrm{mg} \mathrm{kg}^{-1}$ & 31 & 33 & 22 \\
\hline Total $\mathrm{P}, \mathrm{mg} \mathrm{kg}^{-1}$ & 315 & 410 & 225 \\
\hline $\mathrm{CaCO}_{3}, \mathrm{~g} \mathrm{~kg}^{-1}$ & 2.7 & 270 & 2.4 \\
\hline $\mathrm{Fe}, \mathrm{mg} \mathrm{kg}^{-1}$ & 24 & 12 & 49 \\
\hline $\mathrm{Al}, \mathrm{mg} \mathrm{kg}^{-1}$ & 3.5 & 2.1 & 6.2 \\
\hline $\mathrm{Ca}, \mathrm{mg} \mathrm{kg}^{-1}$ & 65 & 113 & 30 \\
\hline $\mathrm{EC}, \mathrm{dS} \mathrm{m} \mathrm{m}^{-1}$ & 0.8 & 0.6 & 0.3 \\
\hline
\end{tabular}

${ }^{a} 1: 1$ soil to water ratio.

All three soils were collected at 0 - to $15-\mathrm{cm}$ depth and were air dried and sieved to pass through a 2-mm screen. Soil chemical and physical analyses were performed at USDA-ARS laboratory at Mississippi State, Mississippi. Soils were analyzed for $\mathrm{pH}$ (1:1, soil to water), texture using hydrometer method (Day 1965), cation exchange capacity (CEC) (Rhoades 1982), total $\mathrm{C}$ and $\mathrm{N}$ using an automated dry combustion analyzer (Model NA $1500 \mathrm{NC}$, Carlo Erba, Milan, Italy), water-extractable P (Olsen and Sommers 1982), Mehlich 3-extractable P (Mehlich 1984), total P (Bowman and Cole 1978), exchangeable Fe (Olsen and Ellis 1982), and exchangeable Al (Yuan 1959).

The presence of free carbonates was determined visually by effervescence when treated with hydrochloric acid (Nelson 1982).

\section{Broiler Litter Collection}

Broiler litter (mixture of broiler manure and sawdust) was collected from a cooperating grower immediately after removing the birds and after decaking. Broiler litter was ground and passed through a 2-mm screen and stored in uncovered plastic jars at $5^{\circ} \mathrm{C}$ until use. Broiler litter sample was characterized (Table 2). Broiler litter total $\mathrm{C}$ and $\mathrm{N}$ were determined by using an automated dry combustion analyzer (Model NA 1500 NC, Carlo Erba, Milan, Italy). Total phosphorus (TP) was determined by dry-ashing of 
Table 2. Selected properties of the broiler litter used for incubation

\begin{tabular}{lc}
\hline Parameter & Broiler litter \\
\hline Dry matter, $\mathrm{g} \mathrm{kg}^{-1}$ & 876 \\
$\mathrm{pH}$ & 7.4 \\
Total $\mathrm{P}, \mathrm{g} \mathrm{kg}^{-1}$ & 15.4 \\
Water-soluble P, $\mathrm{g} \mathrm{kg}^{-1}$ & 2.68 \\
Total N, $\mathrm{g} \mathrm{kg}^{-1}$ & 33.8 \\
$\mathrm{Carbon}_{\mathrm{g} \mathrm{kg}}$ & 388 \\
$\mathrm{~K}, \mathrm{~g} \mathrm{~kg}^{-1}$ & 33.4 \\
$\mathrm{Ca}, \mathrm{g} \mathrm{kg}^{-1}$ & 34.5 \\
$\mathrm{Mg}^{-1} \mathrm{~g} \mathrm{~kg}^{-1}$ & 8.6 \\
$\mathrm{Fe}, \mathrm{mg} \mathrm{kg}^{-1}$ & 648 \\
$\mathrm{NH}_{4}-\mathrm{N}, \mathrm{mg} \mathrm{kg}^{-1}$ & 6,552 \\
$\mathrm{NO}_{3}-\mathrm{N}, \mathrm{mg} \mathrm{kg}^{-1}$ & 16 \\
$\mathrm{C}$ to N ratio & 11 \\
$\mathrm{C}$ to P ratio & 25 \\
$\mathrm{~N}$ to P ratio & 2.3 \\
\hline
\end{tabular}

a 0.5-g sample according to procedures outlined by Southern Cooperative Series (Southern Cooperative Series 1983). Phosphorus fractions including water-soluble phosphorus (WSP), bicarbonate inorganic P (Bicarb-IP), bicarbonate organic P (Bicarb-OP), hydroxide inorganic P (Hydrox-IP), hydroxide organic P (Hydrox-OP), acid-P in the litter were determined by sequential extraction using a modification of the Hedley procedure (Sui, Thompson, and Shang 1999) (Table 3).

\section{Incubation Study}

Broiler litter was mixed with each soil to obtain a total $\mathrm{N}$ content of $0.23 \mathrm{~g} \mathrm{~N} \mathrm{~kg}^{-1}$ soil or $299 \mathrm{~kg} \mathrm{~N} \mathrm{ha}^{-1}$ (assuming incorporation depth of

Table 3. Inorganic and organic fractions of $\mathrm{P}$ in broiler litter

\begin{tabular}{lccccccc}
\hline WSP & $\begin{array}{c}\text { Bicarp } \\
\text { IP }\end{array}$ & $\begin{array}{c}\text { Bicarp } \\
\text { OP }\end{array}$ & $\begin{array}{c}\text { Hydrox } \\
\text { IP }\end{array}$ & $\begin{array}{c}\text { Hydrox } \\
\text { OP }\end{array}$ & $\begin{array}{c}\text { Acid } \\
\text { P }\end{array}$ & $\begin{array}{c}\text { Residual } \\
\text { P }\end{array}$ & $\begin{array}{c}\text { Total } \\
\text { P }\end{array}$ \\
\hline \multicolumn{7}{c}{ m kg $^{-1}$} \\
$17 \%^{a}$ & 5,860 & 620 & 1,388 & 308 & 4,472 & 152 & 15,420 \\
\hline
\end{tabular}

Bicarb IP, bicarbonate inorganic phosphorus; Bicarb OP, bicarbonate organic phosphorus; Hydrox IP, hydroxide inorganic phosphorus; Hydrox IP, hydroxide organic phosphorus.

${ }^{a}$ Percent of total P. 
$15 \mathrm{~cm}$ and a bulk density of $1.3 \mathrm{~g} \mathrm{~cm}^{-3}$ ). This $\mathrm{N}$ recommendation was based on $\mathrm{N}$ requirements of silage corn in Mississippi (MSES 2000). The rate of litter to soil applied was $7.1 \mathrm{~g}$ litter $\mathrm{kg}^{-1}$ soil. For each soil, $200 \mathrm{~g}$ of soil were mixed with litter in 1890-mL (half a gallon) plastic containers. Each plastic container represented an experimental unit. The soils were wetted to $70 \%$ of their field capacity. Soil moisture content at field capacity was determined (Tan 1990). After wetting, each container was loosely sealed with a thin polyethylene sheet $(0.01 \mathrm{~mm})$ to allow gas exchange. The treated and untreated (control) soils were incubated in constant temperature chambers at $18^{\circ} \mathrm{C}, 25^{\circ} \mathrm{C}$, and $32^{\circ} \mathrm{C}$ for up to 90 days and replicated three times. The selected temperatures were representative of the average temperatures registered in the selected soils in Mississippi during the time window when broiler litter is usually applied. Water content was readjusted by weight weekly. Separate containers were used for each sampling time. Each temperature (chamber) containing all soil type was replicated three times. At 2, 5, 10, $15,30,60$, and 90 days after incubation, sets of containers (treated and untreated soils) were removed from the constant temperature chambers, hand mixed with a spatula thoroughly, and 50-g subsamples were taken and stored frozen at $-4{ }^{\circ} \mathrm{C}$ until analyzed. These samples were analyzed for water-soluble P (WSP) and Mehlich 3-extractable P (MEP). Samples were taken at 1 and 90 days after incubation were used for $\mathrm{pH}(1: 1$, soil to water). Samples were taken at the end of incubation study (90 days), were analyzed for $\mathrm{P}$ fractions. Also in a separate growth chamber, the effects of broiler litter application rates of $0,2,5$, and $10 \mathrm{Mg}$ litter ha ${ }^{-1}$ on $\mathrm{P}$ fractions of litter in three different soil types were compared only at a constant temperature of $25^{\circ} \mathrm{C}$ up to 90 days. The temperature of $25^{\circ} \mathrm{C}$ was chosen because it is considered as the most favorable regarding mineralization studies (Hards et al. 1983).

\section{Phosphorus Analysis}

\section{Water-Extractable Phosphorus (WEP)}

Two-gram samples of mixed soil and litter were extracted with $20 \mathrm{~mL}$ of deionized water for $10 \mathrm{~min}$ with shaking (Olsen and Sommers 1982). The samples were centrifuged for $15 \mathrm{~min}(3500 \mathrm{rpm}$ ) and filtered (Whatman \#42). Phosphorus in filtrates was determined as ortho-P by the colorimetric method (Murphy and Riley 1962).

\section{Mehlich 3-Extractable Phosphorus (WEP)}

Two-gram samples of soil and litter were extracted with $20 \mathrm{~mL}$ of a Mehlich 3 solution containing 0.005 $M$ EDTA, $0.15 M$ ammonium fluoride $\left(\mathrm{NH}_{4} \mathrm{~F}\right), 0.01$ $M$ nitric acid $\left(\mathrm{NHO}_{3} \mathrm{H}\right), 0.2 M$ acetic acid $\left(\mathrm{CH}_{3} \mathrm{COOH}\right), 0.25 M$ ammonium 
nitrate $\left(\mathrm{NH}_{4} \mathrm{NO}_{3}\right)$ for 10 min with shaking (Mehlich 1984). Samples were then centrifuged for $15 \mathrm{~min}(3500 \mathrm{rpm}$ ) and filtered (Whatman \#42). After neutralizing acid in the samples, $\mathrm{P}$ in the filtrate was determined by the colorimetric method (Murphy and Riley 1962).

Total Phosphorus (TP)

A 0.25 -gram sample of mixed soil and litter was extracted by digestion with $5 \mathrm{~mL}$ of concentrated $\mathrm{H}_{2} \mathrm{SO}_{4}, 3 \mathrm{~mL}$ of $\mathrm{H}_{2} \mathrm{O}_{2}$, and $1 \mathrm{~mL}$ of $\mathrm{HF}$ (Bowman and Cole 1978). Digested sample was mixed with $50 \mathrm{~mL}$ of deionized water, vortexed, and filtered. Phosphorus in the filtrate was determined by inductively coupled plasma optical emission spectrometry (ICP-OES, Iris Plasma Spectrometry, Thermo Jarrell Ash Corp., Franklin, MA).

\section{Phosphorus Fractionation}

Soil inorganic phosphorus (IP) and organic phosphorus (OP) were fractionated (Sui, Thompson, and Shang 1999). The method involves using a series of successively extractants to remove less-available $\mathrm{P}$ from a soil sample. The extractants and the identifier given to the resulting fraction are as follows: deionized water for water-soluble P (plant-available P), $0.5 M \mathrm{NaHCO}_{3}(\mathrm{pH}$ 8.5) extracts additional plant-available $\mathrm{P}$, and more labile forms of soil organic $\mathrm{P}\left(\mathrm{P}_{\mathrm{o}}\right)$. The more strongly alkaline $(0.1 \mathrm{NaOH})$ solution extracts a portion of labile soil organic $\mathrm{P}\left(\mathrm{P}_{\mathrm{o}}\right)$, partially dissolves iron aluminum phosphates, and desorbs inorganic $\mathrm{P}\left(\mathrm{P}_{\mathrm{i}}\right)$ from the surface of sesquioxides; $0.1 \mathrm{M}$ $\mathrm{HCl}$ solution dissolves acid-soluble inorganic $\mathrm{P}$, mainly $\mathrm{Ca}$ phosphates, and some inorganic $\mathrm{P}$ occluded within sesquioxides is released with partial dissolution of the oxide coatings and residual $\mathrm{P}$, which includes a resistant mixture of occluded inorganic P covered with sesquioxides and nonextracted stable organic P (Tiessen, Stewart, and Moir 1984; Hsu 1989). Phosphorus in all filtrates and neutralized digests was determined by the colorimetric method (Murphy and Riley 1962).

Half-gram samples were sequentially extracted with $30 \mathrm{~mL}$ each of deionized water, $0.5 \mathrm{M} \mathrm{NaHCO}_{3}$ (sodium bicarbonate) $(\mathrm{pH}=8.2), 0.1 \mathrm{M}$ $\mathrm{NaOH}$ (sodium hydroxide), and $0.1 \mathrm{HCl}$ (hydrochloric acid) in a centrifuge tube. Each extraction was of $16 \mathrm{~h}$ of end-to-end shaking. After each extraction, the tubes were centrifuged for $15 \mathrm{~min}(3500 \mathrm{rpm})$ and filtered through a $0.45-\mu \mathrm{m}$ filter. After the final extraction, the residual $\mathrm{P}$ was determined in the soil material left in the tubes by extraction with $\mathrm{H}_{2} \mathrm{SO}_{4}-\mathrm{H}_{2} \mathrm{O}_{2}$ (Tiessen and Moir 1993). The total phosphorus (TP) content of the bicarbonate and hydroxide extracts was also determined following perchloric acid digestion (Olsen and Sommers 1982). Orthophosphate $\mathrm{P}$ in the initial filtrates and in the digests of each soil extract was determined colorimetrically (Murphy and Riley 1962). Absorbance was determined at a wavelength of $712 \mathrm{~nm}$. The organic $\mathrm{P}$ content of bicarbonate and hydroxide extracts was calculated 
as the difference between total $\mathrm{P}$ and inorganic $\mathrm{P}$ contents. The fractions are subsequently referred to as bicarbonate inorganic P (Bicarb-IP), hydroxide inorganic P (Hydrox-IP), acid-P, bicarbonate organic P (Bicarb-OP), hydroxide organic P (Hydrox-OP), and residual P (RP). All analyses were conducted in triplicate and the means are presented. The sequential extraction was used to fractionate the soil $\mathrm{P}$ in separate samples from those used for water-soluble and Mehlich 3P.

\section{Statistical Analysis}

The General Linear Model (GLM) procedure in SAS was used for analyses of variance (SAS 1985). Data were analyzed by using simple regression models, which included linear trends. Differences between means for soil type and incubation temperature were evaluated by using least significant difference (LSD) at the 0.05 probability level.

\section{RESULTS AND DISCUSSIONS}

Total $\mathrm{P}$ and $\mathrm{C}$ contents of broiler litter were 15.4 and $388 \mathrm{~g} \mathrm{~kg}^{-1}$. Watersoluble $\mathrm{P}$ content of the broiler litter was $2.68 \mathrm{~g} \mathrm{~kg}^{-1}$ (Table 1). Sharpley and Moyer (2000) reported $2.85 \mathrm{~g} \mathrm{~kg}^{-1}$ for the mean soluble P content of 24 litter samples collected from a broiler operation prior to land application. Chemical fractionation of the broiler litter indicated that $72 \%$ of total $\mathrm{P}$ was in extractable inorganic forms (38\% Bicarb-IP, 29\% acid-P, and 9\% Hydrox-IP) (Table 3). The predominance of inorganic $\mathrm{P}$ forms in broiler litter is consistent with other studies in poultry litter where inorganic $\mathrm{P}$ was found to be $>85 \%$ (Sharpley and Moyer 2000).

\section{Effects of Soil Properties and Incubation Temperature}

Soil $\mathrm{pH}$

At the beginning of incubation (1 day), application of broiler litter increased soil $\mathrm{pH}$ (Table 4) compared with the initial untreated soil $\mathrm{pH}$ (Table 1). This is possibly related to the liming potential of broiler litter (Tiessen, Stewart, and Moir 1984), which resulted from significant addition of cations such as $\mathrm{NH}_{4}^{+}$, $\mathrm{K}, \mathrm{Ca}, \mathrm{Mg}$, and soluble $\mathrm{C}$ from broiler litter or could be related to bacterial activity and thus the production of the enzyme urease, which breaks down uric acid molecules to simpler $\mathrm{N}$ forms and results in increased $\mathrm{pH}$ (Cabrera et al. 1993). These results are in agreement with Sharpley et al. (1993), who reported that a 0.5 -unit increase in soil $\mathrm{pH}$ resulted from broiler litter applications. Except for Leeper clay loam soil, $\mathrm{pH}$ significantly decreased as 
Table 4. Effects of soil type and incubation temperature on soil $\mathrm{pH}$ in treated soils with broiler litter during a 90-day incubation

\begin{tabular}{|c|c|c|c|c|c|c|c|c|c|}
\hline \multirow[b]{2}{*}{ Treatment } & \multicolumn{3}{|c|}{ Leeper clay loam } & \multicolumn{3}{|c|}{ Grenada silt loam } & \multicolumn{3}{|c|}{ Ruston sandy loam } \\
\hline & $18^{\circ} \mathrm{C}$ & $25^{\circ} \mathrm{C}$ & $32^{\circ} \mathrm{C}$ & $18^{\circ} \mathrm{C}$ & $25^{\circ} \mathrm{C}$ & $32^{\circ} \mathrm{C}$ & $18^{\circ} \mathrm{C}$ & $25^{\circ} \mathrm{C}$ & $32^{\circ} \mathrm{C}$ \\
\hline Untreated 1day & 6.50 & 6.48 & 6.44 & 7.09 & 7.05 & 6.98 & 6.02 & 5.98 & 5.91 \\
\hline $\begin{array}{l}\text { Untreated } \\
90 \text { days }\end{array}$ & 6.47 & 6.46 & 6.41 & 7.04 & 6.99 & 6.90 & 5.95 & 5.89 & 5.80 \\
\hline Change & 0.03 & 0.02 & 0.03 & 0.05 & 0.06 & 0.08 & 0.07 & 0.09 & 0.11 \\
\hline $\begin{array}{l}\text { Average } \\
\text { change/soil }\end{array}$ & & 0.026 & & & 0.063 & & & 0.09 & \\
\hline Treated 1day & 6.58 & 6.54 & 6.47 & 7.11 & 7.06 & 7.00 & 6.07 & 6.02 & 5.92 \\
\hline Treated 90 days & 6.52 & 6.49 & 6.40 & 7.01 & 6.94 & 6.81 & 5.84 & 5.78 & 5.64 \\
\hline Change & 0.06 & 0.05 & 0.07 & 0.10 & 0.12 & 0.19 & 0.23 & 0.24 & 0.28 \\
\hline $\operatorname{LSD}_{(0.05)}$ & NS & NS & NS & 0.063 & 0.072 & 0.12 & 0.11 & 0.11 & 0.14 \\
\hline $\begin{array}{l}\text { Average, } \\
\text { change/soil }\end{array}$ & & 0.06 & & & 0.14 & & & 0.25 & \\
\hline
\end{tabular}

NS, not significant at 0.05 level.

incubation time proceeded from 1 day to 90 days (Table 4). During the organic material decomposition, carbonic gas and protons are produced, which explain the decrease in soil $\mathrm{pH}$ at the end of incubation (Cabrera et al. 1993). These declines in $\mathrm{pH}$ values of the litter-treated soils also could be related to the formation of $\mathrm{NO}_{3}-\mathrm{N}$ from nitrification process (Sanchez-Monedero et al. 2001). Soil pH levels also decreased in soils when incubation temperature increased from $18^{\circ} \mathrm{C}$ to $32^{\circ} \mathrm{C}$. The decreasing $\mathrm{pH}$ at the higher incubation temperature probably related to a greater microbial activity or increase in chemical reactions (i.e., adsorption or precipitation) at higher temperature (Field, Renau, and Kroontij 1985).

In each soil, when the $\mathrm{pH}$ change was averaged across the incubation temperatures, the largest $\mathrm{pH}$ change occurred in Ruston soil in which the soil $\mathrm{pH}$ decreased by 0.25 units. Lower $\mathrm{pH}$ in Ruston soil is probably due to lower soil $\mathrm{pH}$ buffering capacity and greater nitrification potential of the coarse textured soils than fine textured soils (Praveen-Kumar and Aggarwal 1998).

\section{Water-Extractable P (WSP)}

The changes in WSP levels during the 90-day incubation study consisted of four distinct phases. Initially, the water-soluble $\mathrm{P}$ decreased and then rapidly increased and then decreased again and remained at a steady state for the duration of the study (Figure 1). The initial decrease in WSP levels ended between 5 days in Leeper and Grenada to 7 days in Ruston for all 

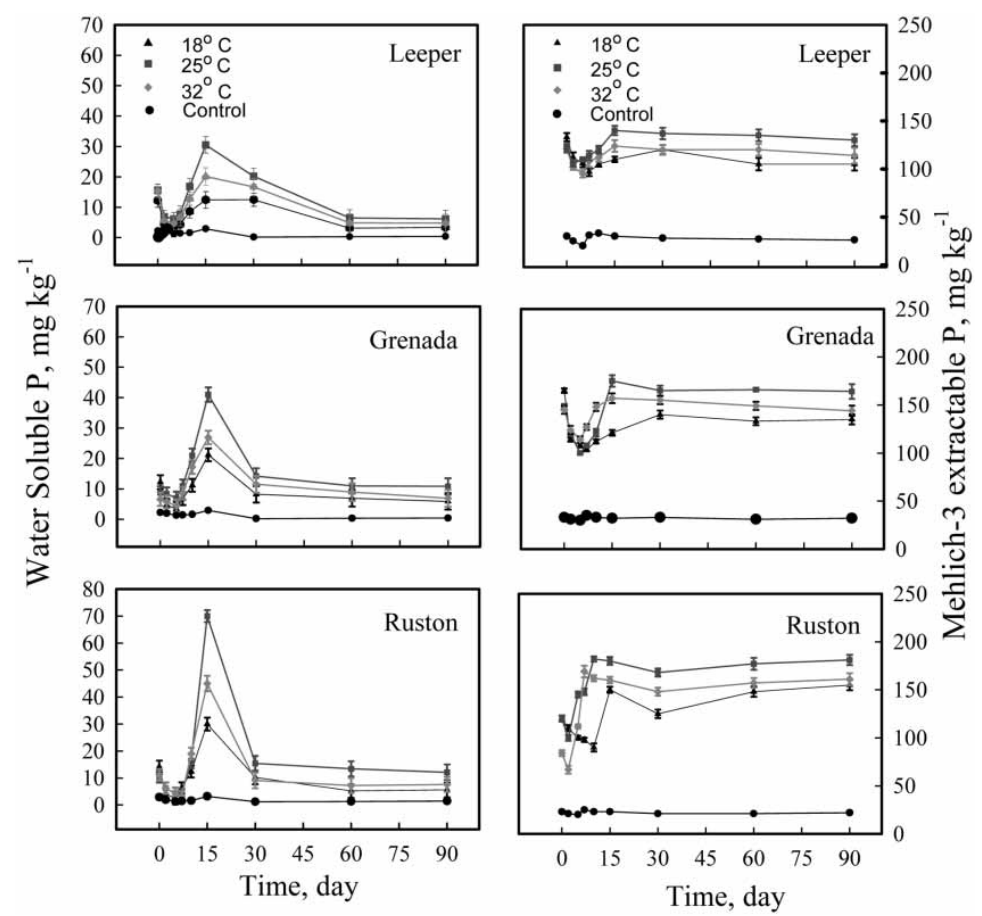

Figure 1. Effect of temperature on water-soluble $\mathrm{P}$ and Mehlich-P in three different soil types amended with broiler litter.

temperatures. This initial decrease in WSP concentrations indicated that it possibly formed insoluble compounds or that it reached to an increase in chemical reactions (i.e., adsorption and precipitation). The rapid increase in WSP is possibly related to the mineralization of organic P compounds in broiler litter and ended after 15 days in all soils (Figure 1). At the third phase, WSP decreased and reached a steady state after 30 days of incubation in Grenada and Ruston soils. However, for Leeper soil, the steady state started after 60 days of incubation (Figure 1). At $32^{\circ} \mathrm{C}$, WSP was less than that at $25^{\circ} \mathrm{C}$, which is related to this reason that elevated temperature increases biological activity and promotes depletion of more soluble $\mathrm{P}$ compared with lower temperature (Akhtar, McCallister, and Eskridge 2002). Water-soluble $\mathrm{P}$ remained highest in Ruston soil at all temperatures (Figure 1), which could be related to its lower clay and organic matter content (Table 1) and, consequently, smaller potential of $\mathrm{P}$ adsorption than Leeper and Grenada soils. These results are in agreement with the work of Mozaffari and Sims (Mozaffari and Sims 1996), who reported that the highest value for WSP was obtained in soils that had low clay and organic matter contents. No significant variation in water-soluble $\mathrm{P}$ with temperature was obtained in untreated soils. 


\author{
Mehlich-3-Extractable P (MEP)
}

Application of broiler litter significantly increased MEP in all three soils. The net increase of MEP at the end of the incubation period was 70, 111, and $133 \mathrm{mg} \mathrm{kg}^{-1}$ at $18^{\circ} \mathrm{C} ; 88,120$, and $142 \mathrm{mg} \mathrm{kg}^{-1}$ at $25^{\circ} \mathrm{C}$; and 100,133 , and $150 \mathrm{mg} \mathrm{kg}^{-1}$ at $32^{\circ} \mathrm{C}$ for Leeper, Grenada, and Ruston soils, respectively. Because the same amount of litter was applied to each soil, the Ruston soil had the greatest increase in MEP compared with the other soil types. The lack of $\mathrm{P}$ retention sites in the coarse textured Ruston could be related to the greatest increase in available $\mathrm{P}$ observed. The observed increase in MEP is consistent with other similar incubation studies. Reddy et al. (1980) reported that MEP was 214 and $49 \mathrm{mg} \mathrm{kg}^{-1}$ in treated and untreated sandy soil, respectively, a net increase of $165 \mathrm{mg} \mathrm{kg}$. Laboratory incubation of several Coastal Plains soils and anaerobically digested poultry litter resulted in an increase in available soil P contents (Field, Renau, and Kroontij 1985). Leeper soil possibly fixed and/or adsorbed more P than Ruston and Grenada soils, as shown by lower amounts of WSP and MEP from the treatments. During the incubation period, MEP in soils treated with broiler litter showed a similar pattern as water-soluble $\mathrm{P}$ (WSP) with three distinct phases (Figure 1). Like WSP, MEP was lower at $18^{\circ} \mathrm{C}$ than at $25^{\circ} \mathrm{C}$ and $32^{\circ} \mathrm{C}$ for the duration of the study. At $32^{\circ} \mathrm{C}$, MEP was less than that at $25^{\circ} \mathrm{C}$. Mehlich 3-extractable $\mathrm{P}$ (MEP) in Ruston soil had the greatest value compared with the other two soils. Because Mehlich 3-extractable $\mathrm{P}$ is a measurement of plant-available $\mathrm{P}$, with less exchange and adsorption sites, MEP will be higher. The extraction of MEP reached a maximum point and remained at a steady state in all soils over time. Similar results were obtained by Preusch et al. (2002), who reported that plant-available $\mathrm{P}$ (MEP) remained at a steady state in the sandy loam soil, but the environmental labile P (WSP) declined over time.

\title{
Soil P Fractions
}

Broiler litter applications resulted in a significant increase in total $\mathrm{P}$ content by 2-, 2.5-, and 3-fold in Leeper, Grenada, and Ruston soils, respectively (Table 5). The sequential fractionation of soil $\mathrm{P}$ into forms of differing availability allows a further evaluation of the disposition of $\mathrm{P}$ in soils treated with broiler litter. Broiler litter application resulted in a significant $(p<0.05)$ increase in all fractions (Table 5). The increase was greater for inorganic than for organic fractions. For example, the bicarbonate inorganic $\mathrm{P}$ (IP) content of broiler litter-treated soils was $84 \%, 71 \%$, and $82 \%$ greater; hydroxide IP 80\%, 68\%, and 58\% greater; and acid IP 80\%, 80\%, and $81 \%$ greater than untreated Leeper, Grenada, and Ruston soils, respectively. However, bicarbonate OP was only 47\%, 58\%, and 60\% and hydroxide OP was $26 \%, 35 \%$, and $34 \%$ greater than untreated Leeper, Grenada, and Ruston soils, respectively. This is consistent with the low C:P ratio of broiler litter (Table 1) in which organic $\mathrm{P}$ in the added litter mineralized to 
Table 5. The distribution of $\mathrm{P}$ fractions in surface $5 \mathrm{~cm}$ of soil treated with broiler litter as influenced by soil type and incubation temperature ${ }^{\dagger}$

\begin{tabular}{|c|c|c|c|c|c|c|c|c|c|c|c|c|c|c|}
\hline \multirow[b]{3}{*}{ Soil } & & & \multicolumn{6}{|c|}{ Inorganic P } & \multicolumn{4}{|c|}{ Organic $\mathrm{P}$} & & \\
\hline & \multicolumn{2}{|c|}{ Total P } & \multicolumn{2}{|c|}{ Bicarb. } & \multicolumn{2}{|c|}{ Hydrox. } & \multicolumn{2}{|c|}{ Acid } & \multicolumn{2}{|c|}{ Bicarb. } & \multicolumn{2}{|c|}{ Hydrox. } & \multicolumn{2}{|c|}{ Residual P } \\
\hline & Unt. & Trt. & Unt. & Trt. & Unt. & Trt. & Unt. & Trt. & Unt. & Trt. & Unt. & Trt. & Unt. & Trt. \\
\hline & \multicolumn{14}{|c|}{$\mathrm{mg} \mathrm{kg}^{-1}$} \\
\hline \multicolumn{15}{|l|}{ Leeper } \\
\hline $18^{\circ} \mathrm{C}$ & 312 & 616 & 25 & 169 & 16 & 78 & 5 & 30 & 33 & 50 & 76 & 103 & 157 & 186 \\
\hline $25^{\circ} \mathrm{C}$ & 310 & 626 & 31 & 184 & 19 & 90 & 9 & 42 & 36 & 60 & 88 & 110 & 127 & 140 \\
\hline $32^{\circ} \mathrm{C}$ & 311 & 629 & 37 & 216 & 20 & 103 & 9 & 48 & 27 & 69 & 84 & 127 & 134 & 166 \\
\hline Average & $311^{\dagger}$ & $624^{\dagger}$ & $31^{\dagger}$ & $190^{\dagger}$ & $18^{\dagger}$ & $90^{\dagger}$ & $8^{\dagger}$ & $40^{\dagger}$ & $32^{\dagger}$ & $60^{\dagger}$ & $83^{\dagger}$ & $113^{\dagger}$ & $139^{\dagger}$ & $164^{\dagger}$ \\
\hline \multicolumn{15}{|l|}{ Grnada } \\
\hline $18^{\circ} \mathrm{C}$ & 417 & 1007 & 64 & 202 & 45 & 135 & 65 & 280 & 57 & 145 & 92 & 144 & 94 & 101 \\
\hline $25^{\circ} \mathrm{C}$ & 414 & 1025 & 67 & 217 & 40 & 150 & 66 & 314 & 26 & 66 & 73 & 112 & 142 & 166 \\
\hline $32^{\circ} \mathrm{C}$ & 410 & 1020 & 69 & 238 & 60 & 165 & 62 & 326 & 16 & 25 & 68 & 108 & 135 & 158 \\
\hline Average & $414^{\dagger}$ & 1017 & $67^{\dagger}$ & $219^{\dagger}$ & $48^{\dagger}$ & $150^{\dagger}$ & $64^{\dagger}$ & $307^{\dagger}$ & $33^{\dagger}$ & $79^{\dagger}$ & $78^{\dagger}$ & $121^{\dagger}$ & $124^{\dagger}$ & $142^{\dagger}$ \\
\hline \multicolumn{15}{|l|}{ Ruston } \\
\hline $18^{\circ} \mathrm{C}$ & 228 & 668 & 25 & 141 & 60 & 143 & 7 & 42 & 19 & 51 & 33 & 51 & 134 & 240 \\
\hline $25^{\circ} \mathrm{C}$ & 225 & 775 & 26 & 143 & 77 & 189 & 8 & 44 & 22 & 54 & 44 & 68 & 155 & 277 \\
\hline $32^{\circ} \mathrm{C}$ & 221 & 770 & 27 & 151 & 82 & 194 & 9 & 43 & 9 & 20 & 45 & 69 & 139 & 293 \\
\hline Average & $225^{\dagger}$ & $731^{\dagger}$ & $26^{\dagger}$ & $145^{\dagger}$ & $73^{\dagger}$ & $175^{\dagger}$ & $8^{\dagger}$ & $43^{\dagger}$ & $17^{\dagger}$ & $42^{\dagger}$ & $41^{\dagger}$ & $63^{\dagger}$ & $143^{\dagger}$ & $270^{\dagger}$ \\
\hline
\end{tabular}

Unt., untreated soil; Trt, treated soil with broiler litter; Bicarb, bicarbonate; Hydrox, hyroxide.

${ }^{\dagger}$ Averages followed by the same letter are not significantly different $(p<0.05)$ as determined by analysis of variance for paired data. 
inorganic $\mathrm{P}$. The accumulation of $\mathrm{P}$ in primarily inorganic forms in soils treated with broiler litter is important to both soil productivity and water quality, in terms of the potential bioavailability of $\mathrm{P}$ in soil and that potential transport in runoff (Sharpley, Smith, and Bain 1993). Overall, most of the applied broiler litter $\mathrm{P}$ accumulated as weekly bound plant-available IP and IP associated with hydrous $\mathrm{Al}$ and $\mathrm{Fe}$ oxides and $\mathrm{Ca}$ precipitates (Table 5). Ruston soil had the highest water-soluble $\mathrm{P}$ fraction (WSP), followed by Grenada and then Leeper. Water-soluble P (WSP) remains highest in Ruston soil at all temperatures because of the coarse texture of the soil and its relative lack of retention sites for $\mathrm{P}$ (Table 6). No significant differences in inorganic and organic $\mathrm{P}$ fractions were found between the $18^{\circ} \mathrm{C}$ and $25^{\circ} \mathrm{C}$ incubation temperatures. At $32^{\circ} \mathrm{C}$, the concentration of plant-available $\mathrm{P}$ fractions (bicarbonate IP and hydroxide IP) significantly increased and water-soluble P (WSP) decreased (Table 6). It is likely that the higher temperature $\left(32^{\circ} \mathrm{C}\right)$ promotes higher biological activity and lower water-soluble $\mathrm{P}$ than the lower temperature. This temperature effect on WSP fraction suggests that application of broiler litter, after the soil has warmed, offers less potential for WSP loss. Concentration of plant-available $\mathrm{P}$ fractions (hydroxide IP and bicarbonate IP) was significantly smaller at $18^{\circ} \mathrm{C}$ and $25^{\circ} \mathrm{C}$ than at $32^{\circ} \mathrm{C}$ (Table 6). The acid IP fraction was not affected by temperature. However, the concentration of acid IP fraction in Grenada soil was much greater $(p<0.001)$ than in Leeper and Ruston soils. The greatest concentration of acid IP fraction in Grenada soil might be related to the greatest level of free $\mathrm{CaCO}_{3}$ in Grenada soil (Table 3), which favored the formation of Ca-P (acid IP) fraction in this soil (Wang, Harris, and Reddy 1995). These variations suggest that soil type value

Table 6. Mean values of $\mathrm{P}$ fraction concentrations for experimental main effects ${ }^{a}$

\begin{tabular}{|c|c|c|c|c|c|c|c|}
\hline \multirow[b]{2}{*}{ Effect } & \multicolumn{4}{|c|}{ Inorganic $\mathrm{P}$} & \multicolumn{2}{|c|}{ Organic P } & \multirow[b]{2}{*}{ Residual } \\
\hline & WSP & Bicarb & Hydrox & Acid & Bicarb & Hydrox & \\
\hline & \multicolumn{7}{|c|}{$\mathrm{mg} \mathrm{P} / \mathrm{kg}$} \\
\hline \multicolumn{8}{|l|}{ Soil } \\
\hline Leeper & $22^{a}$ & $190^{b}$ & $90^{c}$ & $40^{b}$ & $60^{a b}$ & $113^{a}$ & $164^{b}$ \\
\hline Grenada & $34^{a}$ & $219^{a}$ & $150^{b}$ & $307^{a}$ & $79^{a}$ & $129^{a}$ & $142^{b}$ \\
\hline Ruston & $69^{b}$ & $145^{c}$ & $175^{a}$ & $43^{b}$ & $42^{b}$ & $63^{b}$ & $270^{a}$ \\
\hline \multicolumn{8}{|l|}{ Temperature } \\
\hline $18^{\circ} \mathrm{C}$ & $49^{a}$ & $171^{b}$ & $119^{b}$ & $117^{a}$ & $82^{a}$ & $99^{a}$ & $176^{b}$ \\
\hline $25^{\circ} \mathrm{C}$ & $50^{a}$ & $181^{b}$ & $132^{b}$ & $133^{a}$ & $60^{b}$ & $97^{a}$ & $194^{b}$ \\
\hline $32^{\circ} \mathrm{C}$ & $26^{b}$ & $202^{a}$ & $154^{a}$ & $139^{a}$ & $38^{c}$ & $101^{a}$ & $206^{a}$ \\
\hline
\end{tabular}

WSP, water-soluble phosphorus; Bicarb, bicarbonate; Hydrox, hydroxide.

${ }^{a}$ For each $\mathrm{P}$ fractions values in each column followed by the same letter are not significantly different $(p<0.05)$ as determined by analysis of variance. 
should be considered in relationship to $\mathrm{P}$ availability to the environment and for plant availability as well. The lower WSP at $32^{\circ} \mathrm{C}$, when the soil has warmed, than at $25^{\circ} \mathrm{C}$ suggests a possible increase in microbial activity where the $\mathrm{C}$ and $\mathrm{N}$ were added to the soil with litter, thus faster $\mathrm{P}$ immobilization. These results are in agreement with the results of Robinson et al. (1995), who found a decrease in soluble $\mathrm{P}$ during a 28-day incubation study.

Regression analysis was used to determine the relationship between the concentration of soil P fractions and broiler litter applications (Table 7). In the linear models, the slope of each equation reflects the increase in the concentration of a soil $\mathrm{P}$ fraction with each increment of $\mathrm{P}$ applied with poultry litter. Therefore, the greater the slope, the greater an inorganic $\mathrm{P}$ fraction is influenced by applied broiler litter $\mathrm{P}$. The amount of inorganic $\mathrm{P}$ in each fraction decreased in the order of Bicarbonate IP $>$ Hydroxide IP $>$

Table 7. Linear regression expressions that describe the change in concentration of each $\mathrm{p}$ fraction $(\mathrm{Y})$ as a function of broiler litter application rate $(\mathrm{X})$

\begin{tabular}{|c|c|c|c|}
\hline Fraction & Linear regression & $\mathrm{R}^{2}$ & $\begin{array}{c}\text { Level of } \\
\text { significane }\end{array}$ \\
\hline \multicolumn{4}{|l|}{ Leeper } \\
\hline Water soluble P & $Y=1.35 X+3.6$ & 0.98 & $* *$ \\
\hline Bicarbonate IP & $Y=7.36 X+89$ & 0.86 & $* *$ \\
\hline Bicarbonate OP & $Y=1.14 X+17$ & 0.58 & NS \\
\hline Hydroxide IP & $Y=4.17 X+33$ & 0.97 & $* *$ \\
\hline Hydroxide IP & $Y=1.25 X+63$ & 0.47 & NS \\
\hline Acid P & $Y=2.86 X+28$ & 0.70 & $*$ \\
\hline Residual P & $Y=1.13 X+156$ & 0.79 & $*$ \\
\hline \multicolumn{4}{|l|}{ Grenada } \\
\hline Water soluble P & $Y=2.25 X+4.5$ & 0.70 & $* *$ \\
\hline Bicarbonate IP & $Y=8.3 X+71$ & 0.91 & $* *$ \\
\hline Bicarbonate OP & $\mathrm{Y}=0.11 \mathrm{X}+31$ & 0.55 & NS \\
\hline Hydroxide IP & $Y=6.9 X+98$ & 0.90 & $* *$ \\
\hline Hydroxide OP & $Y=0.15 X+33$ & 0.69 & NS \\
\hline Acid P & $Y=9.3 X+224$ & 0.98 & $* *$ \\
\hline Residual P & $Y=0.10 X+67$ & 0.71 & $*$ \\
\hline \multicolumn{4}{|l|}{ Ruston } \\
\hline WSP & $Y=3.6 X+6.2$ & 0.97 & $* *$ \\
\hline Bicarbonate IP & $Y=6.1 X+53$ & 0.91 & $* *$ \\
\hline Bicarbonate OP & $\mathrm{Y}=0.01 \mathrm{X}+31$ & 0.55 & NS \\
\hline Hydroxide IP & $\mathrm{Y}=7.1 \mathrm{X}+78$ & 0.98 & $* *$ \\
\hline Hydroxide OP & $Y=0.06 X+28$ & 0.69 & NS \\
\hline Acid P & $Y=5.5 X+18$ & 0.99 & $* *$ \\
\hline Residual P & $Y=1.2 X+52$ & 0.71 & $*$ \\
\hline
\end{tabular}

${ }^{* *}$ Significant at the 0.001 level of probability; ${ }^{*}$ significant at the 0.05 level of probability; NS, not significant; IP, inorganic phosphorus; OP, organic phosphorus. 
Acid IP $>$ WSP for Leeper; in the order of Acid IP $>$ Bicarbonate IP $>$ Hydroxide IP $>$ WSP for Grenada; and in the order of Hydroxide IP $>$ Bicarbonate IP $>$ Acid IP $>$ WSP for Ruston soil. The lower organic P fractions in the Ruston soil compared with the other two soils may have been caused by greater mineralization of applied organic $\mathrm{P}$ in a coarse textured Ruston than fine textured Leeper and Grenada soils. The amount of organic P content decreased in the order of Leeper $>$ Grenada $>$ Ruston soil.

\section{CONCLUSIONS}

The results of this study indicated that the coarse textured Ruston soil contained a significantly higher concentration of WSP than did the fine textured Leeper and Grenada soils. If water-soluble $\mathrm{P}$ has the potential to loss in surface water, then soil type should be used as a primary criterion of broiler litter application rate. At $32^{\circ} \mathrm{C}$, the concentration of plant-available $\mathrm{P}$ fractions (bicarbonate IP and hydroxide IP) significantly increased and WSP decreased. As a result, monitoring of $\mathrm{P}$ enrichment following broiler litter application should extend beyond immediately available water-soluble $\mathrm{P}$ as is suggested in the literature that these fractions are biologically available but less available than water-soluble P. It is likely that the higher temperature $\left(32^{\circ} \mathrm{C}\right)$ promotes higher biological activity and lower watersoluble $\mathrm{P}$ than lower temperature. This temperature effect on WSP fraction suggests that application of broiler litter, after the soil has warmed, offers less potential for WSP loss. Use of this information will help to evaluate the fate of $\mathrm{P}$ in added litter and may be used in land application guidelines that protect water quality.

\section{REFERENCES}

Akhtar, M., McCallister, D.L., and Eskridge, K.M. (2002) Availability and fractionation of phosphorus in sewage sludge amended soils. Communications in Soil Science and Plant Analysis, 33 (13\&14): 2057-2068.

Bowman, R.A. and Cole, C.V. (1978) An exploratory method for fractionation of organic phosphorus from grassland soils. Soil Science, 125 (2): 95-100.

Cabrera, M.L., Chiang, S.C., Merka, W.C., Thopson, S.A., and Pancorbo, O.C. (1993) Nitrogen transformation in surface-applied poultry litter: Effect of litter physical characteristics. Soil Science Society of America Journal, 57: 1519-1525.

Chang, S.C. and Jackson, M.L. (1957) Fractionation of soil phosphorus in soils. Soil Science, 84: 133-144.

Cox, A.E., Camberato, J.J., and Smith, B.R. (1997) Phosphate availability and inorganic transformation in an alum sludge-affected soil. Journal of Environmental Quality, 26: 1393-1398.

Cross, A.F. and Schlesinger, W.H. (1995) A literature review and evaluation of the Hedley fractionation: application to the biogeochemical cycle of soil phosphorus in natural ecosystems. Geoderma, 64: 197-211. 
Day, P.R. Particle Fractionation and Particle Size Analysis. In Methods of soil analysis, Part 1; Black, C.A., Evans, D.D., White, J.L., Ensminger, I.E. and Clark, F.E., eds.; American Society of Agronomy: Madison, Wisconsin; Vol. 9, 82-84; Agron. Monogr. 1965.

Field, J.A., Renau, R.B., and Kroontij, W. (1985) Effect of anaerobically digest poultry manure on soil phosphorus adsorption and extractability. Journal of Environmental Quality, 14: 105-107.

Gale, P.M., Mullen, M.D., Cieslik, C., Tylor, D.D., Duck, B.N., Kirchner, M., and McClure, J. (2000) Phosphorus distribution and availability in response to dairy manure applications. Commununications in Soil Science and Plant Analysis, 31: $553-565$.

Grierson, P.F., Comerford, N.B., and Jokela, E.J. (1999) Phosphorus mineralization and microbial biomass in a Florida Spodosol: effects of water potential, temperature and fertilizer application. Biology and Fertility Soils, 28 (3): 244-252.

Hards, A., Bar-Yosef, B., Davidov, S., and Sofer, M. (1983) Effect of temperature and soil type on mineral $\mathrm{N}$ release from poultry litter and dairy manure. Soil Science Society of America Journal, 47: 1129-1133.

Hsu, P.H. (1989) Aluminum oxides and oxyhydroxides. In Minerals in Soil Environments, 2nd Ed.; Dixon, J.B. and Weed, S.B., eds.; Soil Science Society of America: Madison, Wisconsin, 331-378.

Kumar, P. and Aggarwal, R.K. (1998) Interdependence of ammonia volatilization and nitrification in arid soils. Nutrient Cycling in Agroecosystems, 51 (3): 201-207.

Malone, G.W. (1992) Nutrient enrichment in integrated broiler production systems. Poultry Science, 7: 1117-1122.

Mehlich, A. (1984) Mehlich 3 soil test extractant. Communications in Soil Science and Plant Analysis, 15: 1409-1416.

Mozaffari, M. and Sims, J.T. (1996) Phosphorus transformations in poultry litteramended soils of the Atlantic coastal plain. Journal of Environmental Quality, 25: $1357-1365$.

MSES (2000) A Guide to the Corn Fertilization; Mississippi State University Extension Service: Mississippi, Mississippi State, 2000; MSES, Inf. Sheet \#864.

Murphy, J. and Riley, J.P. (1962) A modified single solution method for the determination of phosphorus in natural waters. Analytica Chimica Acta, 27: 31-36.

Nair, V.D., Graetz, D.A., and Portier, K.M. (1995) Forms of phosphorus in soil profiles from dairies of south Florida. Soil Science Society of America Journal, 59: $1244-1249$.

Nelson, R.E. (1982) Carbonate and gypsum. In Methods of Soil Analysis, Part 2; Page, A.L., Miller, R.H. and Keeney, D.R., eds.; American Society of Agronomy: Madison, Wisconsin, 181-197.

Olsen, R.V. and Ellis, R. (1982) Exchangeable iron in soil. In Methods of Soil Analysis, Part 2; Page, A.L., Miller, R.H. and Keeney, D.R., eds.; American Society of Agronomy: Madison, Wisconsin, 301-312.

Olsen, S.R. and Sommers, L.E. (1982) Phosphorus. In Methods of Soil Analysis, Part 2; Page, A.L., Miller, R.H. and Keeney, D.R., eds.; American Society of Agronomy: Madison, Wisconsin, 403-429.

Preusch, P.L., Adler, P.R., Sikora, L.J., and Tworkoski, T.J. (2002) Nitrogen and phosphorus availability in composted and uncomposted poultry litter. Journal of Environmental Quality, 31: 2051-2057.

Reddy, K.R., Overcash, M.R., Khaleel, R., and Westerman, P.W. (1980) Phosphorus adsorption desorption characteristics of two soils utilized for disposal of animal wastes. Journal of Environmental Quality, 9 (1): 86-92. 
Rhoades, J.D. (1982) Cation exchange capacity. In Methods of Soil Analysis, Part 2; Page, A.L., Miller, R.H. and Keeney, D.R., eds.; American Society of Agronomy: Madison, Wisconsin, 149-157.

Robinson, J.S., Sharpley, A.A., and Smith, S.J. (1995) The effect of animal manure application on the forms of soil phosphorus. In Animal Waste and the Land-Water Interface; Steele, Kenneth, ed.; Lewis Publishers: New York, 43-48.

Sanchez-Monedero, M.A., Roig, A., Paredes, C., and Bernal, M.P. (2001) Nitrogen transformation during organic waste composting by the Rutgers system and its effects on $\mathrm{pH}, \mathrm{EC}$, and maturity of the composting mixtures. Bioresources Technology, 78 (3): 301-308.

SAS (1985) The SAS System for Windows; SAS Institute: Cary, North Carolina.

Sharpley, A.N. and Menzel, R.G. (1987) The impact of soil and fertilizer phosphorus on the environment. Advances in Agronomy, 41: 297-319.

Sharpley, A. and Moyer, B. (2000) Phosphorus forms in manure and compost and their release during simulated rainfall. Journal of Environmental Quality, 29: 1462-1469.

Sharpley, A.N., Smith, S.J., and Bain, W.R. (1993) Nitrogen and phosphorus fate from long-term poultry litter application to Oklahoma soils. Soil Science Society of American Journal, 57: 1131-1137.

Sharpley, A.N., Troeger, W.W., and Smith, S.J. (1991) The measurements of bioavailable phosphorus in agricultural runoff. Journal of Environmental Quality, 20: $235-238$.

Smeck, N.E. (1985) Phosphorus dynamics in soils and landscapes. Geoderma, 36: $185-199$.

Smith, C.K., Munson, A.D., and Coyea, M.R. (1998) Nitrogen and P release from humus and mineral soil under black spruce forests in central Quebec. Soil Biology and Biochemistry, 30 (12): 1491-1500.

Southern Cooperative Series. In Reference Soil Test Methods for the Southern Region of the United States; Georgia Agricultural Experiment Station: Athens, Georgia, 1983; Southern Cooperative Series, Bull. No. 289.

Sui, Y., Thompson, M.L., and Shang, C. (1999) Fractionation of phosphorus in a Mollisol amended with biosolids. Soil Science Society of America Journal, 63: $1174-1180$.

Tan, K.H. (1990) Measurement of field capacity water. In Soil Sampling: Preparation and Analysis; Marcel Dekker, Inc.: New York, 67-68.

Tiessen, H. and Moir, J.O. (1993) Characterization of available P by sequential extraction. In Soil Sampling and Method of Analysis; Carter, M.R., ed.; Lewis Publishers: Chelsea, Michigan, 75-86.

Tiessen, H., Stewart, J.W.B., and Moir, J. (1984) Changes in organic and inorganic phosphorus composition of two grassland soils and their particle-size fractions during 60-90 years of cultivation. Journal of Soil Science, 34: 815-823.

Torbert, H.A., Prior, S.A., and Rogers, H.H. (1995) Elevated atmospheric carbon dioxide effects on cotton residue decomposition. Soil Science Society of America, 59: $1321-1328$.

Vaithiyanathan, P. and Correll, D.L. (1992) The Rhode River watershed: phosphorus distribution and export in forest and agricultural soils. Journal of Environmental Quality, 21: 280-288.

Wang, H.D., Harris, W.G., and Reddy, K.R. (1995) Stability of phosphorus forms in dairy impacted soils under column leaching by synthetic rain. Ecological Engineering, 24: 324-329.

Yuan, T.L. (1959) Determination of exchangeable aluminum in soils by titration method. Soil Science, 88: 164-167. 